\title{
KIT NP_000213.1:p.N822Y
}

National Cancer Institute

\section{Source}

National Cancer Institute. KIT NP 000213.1:p.N822Y. NCI Thesaurus. Code C155708.

A change in the amino acid residue at position 822 in the mast/stem cell growth factor receptor Kit protein where asparagine has been replaced by tyrosine. 